\title{
Formulasi Sediaan Krim Pelembab Ekstrak Air Buah Pepaya (Carica Papaya L.)
}

\author{
Kadek Sri Utami Ningsih ${ }^{\left(a^{*}\right.}$, Farida Lanawati Darsono ${ }^{(a)}$, Sumi Wijaya ${ }^{(a)}$ \\ ${ }^{a}$ Fakultas Farmasi, Universitas Katolik Widya Mandala Surabaya, Surabaya, Indonesia
}

Buah pepaya dapat dimanfaatkan sebagai bahan pelembab karena memiliki mekanisme kerja sebagai humektan yang mampu mengurangi terjadinya penguapan air dipermukaan kulit karena mengandung sukrosa. Penelitian ini bertujuan untuk mengetahui pengaruh peningkatan konsentrasi ekstrak air buah pepaya terhadap evaluasi mutu fisik, efektivitas, keamanan, aseptabilitas, serta stabilitas sediaan krim pelembab ekstrak air buah pepaya (Carica papaya L.). Pada penelitian terdiri dari 3 formula sediaan krim mengandung ekstrak dengan konsentrasi berturutturut 10\% (formula 1), 20\% (formula 2), 30\% (formula 3), serta 3 formula blangko yaitu basis saja (blangko 1), dan basis tanpa ekstrak serta tanpa bahan pelembab sintetik (blangko 2). Evaluasi yang dilakukan meliputi parameter uji seperti uji mutu fisik yang meliputi organoleptis, pH, viskositas, tipe emulsi, daya sebar, homogenitas, tercucikan air, dan daya lekat. Pengujian efektivitas sediaan krim ekstrak buah papaya sebagai pelembab di permukaan kulit menggunakan metode Sorption Desorption Test secara in vitro. Pengujian keamanan meliputi uji iritasi dan uji aseptabilitas (hedonic test). Pengujian stabilitas meliputi suhu kamar, sentrifugasi dan cycling test. Data dianalisis menggunakan oneway ANOVA kemudian dilanjutkan dengan post hoc Tukey. Hasil pengujian menunjukkan bahwa peningkatan konsentrasi ekstrak berpengaruh secara signifikan terutama terhadap efektivitas sediaan, dimana semakin besar konsentrasi ekstrak air buah pepaya (Carica papaya L.) yang ditambahkan maka semakin tinggi pula kemampuan melembabkan kulit serta menghasilkan sediaan dengan pH sebesar 6,04, viskositas sebesar $159710 \mathrm{cps}$, daya sebar sebesar 3,63 cm, volume tercucikan air sebanyak $13,48 \mathrm{ml}$, daya lekat sebesar 60,05 detik, dan stabilitas sediaan yang tetap stabil selama penyimpanan. Formula yang terbaik adalah formula 3 dengan konsentrasi ekstrak $30 \%$.

Kata Kunci : Carica papaya, gula, krim, pelembab

\section{Formulation of Moisturizing Cream Containing Aquoeus Extract of Papaya (Carica Papaya L.) Fruit}

Sucrose in papaya fruit was used as a moisturizer because it has worked as humectants, which reduce water evaporation on the surface of the skin. The purpose of this research was to determine the effect of the increasing concentrations of water extract of papaya fruit to evaluate its physical quality, effectiveness, safety, acceptability, and stability of the moisturizing cream water extract of papaya (Carica papaya L.). In this study, it used 3 formulas containing the extract of papaya fruit at concentration of $10 \%$ (formula 1), $20 \%$ (formula 2), $30 \%$ (formula 3 ), also blank containing base only, and base without extract and without moisturizing agent. The physical quality tests include organoleptic, $\mathrm{pH}$, viscosity test, emulsion type test, dispersive power test, homogeneity, water washed power and adhesion test. The effectiveness of mouisturizer effect on the skin was tested with in vitro method: Sorption Desorption Test. Savety testing include irritation test and acceptability test. The data was analyzed using oneway ANOVA then continued with post hoc Tukey. The results showed that the increasing concentrations of the extract provides significant effect on efectivity, wherein the greater the concentration of water extract of papaya fruit (Carica papaya L.) were added, then the higher the ability to moisturize the skin and produce of moisturizer cream with pH test 6.04, viscosity $159710 \mathrm{cps}$, dispersive power $3.63 \mathrm{~cm}$, water washed power $13.48 \mathrm{ml}$, adhesion 6005 second, and moisturizer cream stable during storage. The best formula is the formula 3 with a concentration extract of $30 \%$.

Keywords: Carica papaya, cream, moisturizer, sugar.

${ }^{*}$ Corresponding author: Fakultas Farmasi Universitas Katolik Widya Mandala Surabaya, Jl. Raya Kalisari Selatan No. 1 Surabaya, e-mail: sriutaminingsih18@gmail.com 


\section{PENDAHULUAN}

Indonesia merupakan negara tropis dengan paparan sinar matahari yang berlebih sehingga berisiko tinggi terhadap berbagai kerusakan kulit. Salah satu dampak dari paparan sinar matahari yang berlebih yaitu menyebabkan terjadinya penguapan air di permukaan kulit sehingga menyebabkan kulit menjadi kering. Kulit kering biasanya ditandai dengan permukaan kulit yang terasa kaku, kasar, kusam, bersisik bahkan kemerahan (Dewi, 2010). Secara alamiah kulit mampu untuk melindungi diri dari berbagai tanda-tanda kerusakan kulit dengan adanya tabir lemak di atas kulit yang diperoleh dari kelenjar lemak serta adanya lapisan luar kulit yang berfungsi sebagai sawar kulit. Namun dalam kondisi tertentu faktor perlindungan alamiah (Natural Moisturizing Factor/ NMF) tersebut tidak mencukupi. Oleh karena itu, dibutuhkan perlindungan tambahan non alamiah yaitu dengan cara penggunaan kosmetik pelembab kulit (Wasitaatmadja, 1997).

Bahan alam yang dapat dimanfaatkan sebagai pelembab salah satunya adalah buah pepaya. Kandungan dalam buah pepaya yang dimanfaatkan sebagai bahan pelembab adalah kandungan karbohidrat dari golongan gula terutama sukrosa. Selain itu buah ini juga mengandung berbagai gizi dan vitamin seperti vitamin A, B1 dan C yang juga bermanfaat untuk menangkal radikal bebas (Desai and Wagh, 1995). Komposisi gula dalam buah pepaya terdiri dari sukrosa 48,3\%, glukosa 29,8\%, dan fruktosa 21,9\% (Inglet and Charalambous, 1979). Kandungan sukrosa dalam pepaya memiliki mekanisme kerja sebagai humektan sehingga mampu mengikat air di udara atau lingkungan serta dapat mereduksi penguapan air di kulit, sehingga kelembaban kulit akan terjaga dan kulit tidak akan menjadi kering (Lubis dkk, 2012). Pada penelitian sebelumnya yang dilakukan Ferida (2011) dikatakan bahwa semakin tinggi konsentrasi ekstrak kental buah pepaya $(2,5 \%$, $5 \%, 7,2 \%$ dan $10 \%$ ) yang ditambahkan maka kemampuan mengurangi penguapan air di kulit juga akan meningkat. Namun, pada penelitian tersebut sediaan krim dengan konsentrasi ekstrak kental pepaya $7,5 \%$ dan $10 \%$ cenderung kurang stabil selama penyimpanan. Berdasarkan hal tersebut, maka pada penelitian ini akan digunakan ekstrak buah pepaya dalam bentuk kering yang lebih stabil serta dilakukan peningkatan konsentrasi penggunaan ekstrak buah pepaya $10 \%, 20 \%$, dan $30 \%$ dengan tujuan untuk meningkatkan kemampuan sebagai pelembab (mouisturizing effect) dengan mengurangi penguapan air di kulit serta pengaruhnya terhadap sifat mutu fisik sediaan, keamanan, aseptabilitas dan stabilitas sediaan krim pelembab ekstrak air kering buah pepaya (Carica papaya L).

\section{METODE PENELITIAN}

\section{Alat}

Alat-alat gelas, mortir, stamper, neraca analitik (Sartorius BP 110S, Jerman), alat uji susut pengeringan (Infrared Mositurizer Balance, model F1-A, Jerman), alat pH meter (Methrom 620, Switzerland), Viscometer Brookfield (Synchro-Letic LVT, Stoughton, MA, USA), oven (Memmert, Germany), kertas saring Whatman, penangas air.

\section{Bahan}

Ekstrak kering buah pepaya (Carica papaya L.) yang diperoleh dari PT. Natura Laboratoria Prima, asam stearat (PT. Sumi Asih, Indonesia), setil alkohol (PT. KLK OLEO, Malaysia), trietanolamin (PT. Cortico Mulia, Indonesia), sorbitol (PT. Samator Intiperoksida, Indonesia), propilen glikol (Dow Chemical Pasific, Singapore), metilparaben (PT. Clariant Switzerland), propilparaben (PT. Clariant, Switzerland), natrium metabisulfit (PT. Clariant Switzerland), etanol pro analisa (Mallinckrodt Baker, Inc., Phillipsburg), etanol teknis 96\% (CV. Solvenindo, Indonesia), Isopropil miristat (PT. KLK OLEO, Malaysia) dan akuades.

\section{Bahan ekstrak air kering buah pepaya}

Ekstrak kering buah pepaya diperoleh dari PT. Natura Laboratoria Prima, Jakarta. Buah pepaya diekstraksi menggunakan metode perasan dengan pelarut penyari air, setelah itu dipekatkan menggunakan penambahan pengisi yaitu maltodextrin dengan perbandingan antara ekstrak kering dan maltodextrin 7:3 (b/b) lalu dikeringkan menggunakan metode spray drying.

\section{Standarisasi parameter non spesifik dan spesifik ekstrak air kering buah pepaya}

Standarisasi parameter non spesifik meliputi pengujian kadar air, susut pengeringan, kadar abu total, kadar abu tidak larut asam dan kadar abu larut air. Standarisasi parameter spesifik meliputi pengujian organoleptis, sifat fisik, kadar sari larut air dan kadar sari larut etanol (DitJen POM, 2000).

\section{Penentuan identitas zat berkhasiat sukrosa secara kualitatif}

Penentuan ini menggunakan metode uji Molisch dengan cara menimbang sukrosa sejumlah $100 \mathrm{mg}$ kemudian dilarutkan dengan menggunakan pelarut air sebanyak $10 \mathrm{ml}$ sampai larut. Larutan tersebut dimasukkan ke dalam tabung reaksi dan ditambahkan $2 \mathrm{ml}$ larutan ekstrak atau sediaan kemudian ditambahkan 2 tetes pereaksi Molisch melalui dinding tabung reaksi, selanjutnya ditambahkan asam sulfat pekat sebanyak $5 \mathrm{ml}$ tunggu hingga larutan bereaksi dan memberikan hasil yang positif ditandai dengan terbentuknya cincin berwarna ungu (Kumbasari, 2015).

Pembuatan sediaan krim pelembab ekstrak air kering buah pepaya (Carica papaya L.)

Bahan-bahan yang digunakan dalam formulasi sediaan dapat dilihat pada Tabel 1. Bahan yang tergolong dalam fase minyak seperti asam stearat 
dan setil alkohol serta bahan yang tergolong fase air seperti trietanolamin, sorbitol, metal paraben, propilen glikol ditimbang dengan seksama kemudian dilebur di atas waterbath pada suhu $\pm 70^{\circ} \mathrm{C}$. Kedua fase tersebut dicampurkan ke dalam mortir panas dan diaduk konstan hingga terbentuk massa krim.
Selanjutnya ekstrak kering buah pepaya dilevigasi dengan sisa akuades hingga homogen, kemudian ditambahkan secara perlahan ke dalam campuran basis krim yang telah terbentuk, digerus konstan hingga terbentuk massa krim yang homogen.

TABEL 1. Formula Sediaan Krim Pelembab Ekstrak Air Buah Pepaya (Carica papaya L.)

\begin{tabular}{|c|c|c|c|c|c|c|}
\hline Bahan & $\begin{array}{c}\text { Formula } 1 \\
\text { (\%) }\end{array}$ & $\begin{array}{c}\text { Formula } 2 \\
\text { (\%) }\end{array}$ & $\begin{array}{c}\text { Formula } 3 \\
\text { (\%) }\end{array}$ & $\begin{array}{c}\text { Blangko I } \\
\text { (\%) }\end{array}$ & $\begin{array}{c}\text { Blangko } \\
\text { II } \\
\text { (\%) }\end{array}$ & Fungsi \\
\hline $\begin{array}{l}\text { Ekstrak } \\
\text { pepaya }\end{array}$ & 10 & 20 & 30 & - & - & Bahan aktif \\
\hline Asam stearat & 12 & 12 & 12 & 12 & 12 & Emulgator \\
\hline Setil alkohol & 0,5 & 0,5 & 0,5 & 0,5 & 0,5 & $\begin{array}{c}\text { Stiffening } \\
\text { aqent }\end{array}$ \\
\hline $\begin{array}{c}\text { Sorbitol } \\
\text { Propilen glikol }\end{array}$ & 5 & 5 & 5 & 5 & - & $\begin{array}{l}\text { Humektan } \\
\text { Humektan }\end{array}$ \\
\hline TEA & $\begin{array}{l}3 \\
1\end{array}$ & $\begin{array}{l}3 \\
1\end{array}$ & $\begin{array}{l}3 \\
1\end{array}$ & $\begin{array}{l}3 \\
1\end{array}$ & $\overline{1}$ & $\begin{array}{l}\text { Humektan } \\
\text { Emulgator }\end{array}$ \\
\hline $\begin{array}{l}\text { Natrium } \\
\text { metabisulfit }\end{array}$ & 0,2 & 0,2 & 0,2 & 0,2 & 0,2 & Antioksidan \\
\hline Metilparaben & 0,18 & 0,18 & 0,18 & 0,18 & 0,18 & Pengawet \\
\hline $\begin{array}{l}\text { Propilparaben } \\
\text { Aquades }\end{array}$ & $\begin{array}{c}0,02 \\
\mathrm{Ad} 100 \mathrm{ml}\end{array}$ & $\begin{array}{c}0,02 \\
\text { Ad } 100 \mathrm{ml}\end{array}$ & $\begin{array}{c}0,02 \\
\text { Ad } 100 \mathrm{ml}\end{array}$ & $\begin{array}{c}0,02 \\
\text { Ad } 100 \mathrm{ml}\end{array}$ & $\begin{array}{c}0,02 \\
\text { Ad } 100 \mathrm{ml}\end{array}$ & $\begin{array}{l}\text { Pengawet } \\
\text { Pelarut }\end{array}$ \\
\hline
\end{tabular}

Evaluasi sediaan krim pelembab ekstrak air kering buah pepaya (Carica papaya L.)

Evaluasi sediaan krim meliputi uji mutu fisik yang terdiri dari pengamatan organoleptis, $\mathrm{pH}$, tipe emulsi (Panda, 2000), viskositas (Aswal, Kalra and Rout, 2013), daya sebar (Garg et al, 2002), homogenitas (Voigt, 1994), tercucikan air (Anggraini, Malik dan Susiladewi, 2011), dan daya lekat. Sedangkan uji efektivitas sediaan sebagai pelembab menggunakan metode Sorption Desorption Test (SDT) dilanjutkan dengan uji keamanan sediaan, uji aseptabilitas sediaan dan uji stabilitas sediaan (Herawati, 2006; Barel, Paye and Maibach, 2009).

Adapun proses pengujian daya melembabkan dengan SDT (Sorbtion Desorbtion Test) dimulai dengan pembuatan gel hidrofilik yang mengandung CMC 3\% kemudian disiapkan membran milipore (Whatmann) yang sudah diimpregnasi dengan isopropil miristat selama 24 jam sampai jumlah isopropil miristat yang menempel pada membran milipore konstan. Selanjutnya dilakukan pemeriksaan daya pelembab sediaan krim ekstrak buah papaya tersebut dengan cara gel CMC 3\% dimasukkan ke dalam cawan petri kemudian ditutup dengan membran milipore yang telah diimpregnasi dan diikat. Sediaan pelembab sebanyak $2 \mathrm{~g}$ dioleskan merata pada permukaan membran kemudian ditimbang. Sampel uji disimpan dalam oven yang diatur suhunya yaitu $32 \pm 0,5^{\circ} \mathrm{C}$ (Herawati, 2006). Pada jam ke-0,5, 1, 2, dan 4 dilakukan penimbangan dan pencatatan bobot sampel uji. Perhitungan hasil berdasarkan jumlah air yang hilang yang ditunjukkan dengan nilai $[\mathrm{AUC}]_{\text {total }}$ dari selisih bobot sampel (g) terhadap waktu (4 jam). Semakin besar nilai [AUC $]_{\text {total }}$ yang diperoleh menunjukkan jumlah air yang hilang dari kulit akan semakin besar pula. Semakin kecil nilai $[\mathrm{AUC}]_{\text {total }}$ yang diperoleh, maka kemampuan kulit untuk menahan kehilangan air akan semakin besar dan kemampuan melembabkannya akan lebih baik. Sediaan krim pelembab ekstrak air buah semangka pada penelitian ini dikatakan efektif bila nilai $[\mathrm{AUC}]_{\text {total }}$ formula yang mengandung ekstrak lebih kecil daripada nilai $[\mathrm{AUC}]_{\text {total }}$ formula blangko (Barel, Paye and Maibach, 2009).

Uji stabilitas fisik sediaan krim esktrak buah pepaya meliputi pengamatan organoleptis, $\mathrm{pH}$, viskositas pada penyimpanan dengan suhu $27 \pm 2^{\circ} \mathrm{C}$ selama 4 minggu, suhu penyimpanan $4^{\circ} \mathrm{C}$ selama 24 jam, lalu dipindahkan ke dalam oven dengan suhu $40 \pm 2^{\circ} \mathrm{C}$ (satu fase) dengan menggunakan metode cycling test, metode sentrifugasi (selama 30 menit - $3000 \mathrm{rpm}$ ) (Djajadisastra, 2004).

\section{Metode Analisa Data Statistik}

Hasil evaluasi sediaan selanjutnya dianalisis menggunakan software SPSS for windows 17.0 untuk mengetahui ada atau tidaknya perbedaan yang bermakna pada tiap bets dan formulanya. Metode statistik yang digunakan untuk analisa data antar bets yang bersifat parametrik dengan metode Independent $t$ test dan yang bersifat non parametrik dengan metode Mann Whitney. Sedangkan data parametrik antar formula dengan oneway ANOVA dan non parametrik dengan metode Kruskal Wallis (Jones, 2010).

\section{HASIL DAN PEMBAHASAN}

Standarisasi non spesifik dan spesifik ekstrak kering buah pepaya diperoleh hasil bahwa 
ekstrak tersebut memenuhi spesifikasi yang ada dan dalam kondisi yang baik sehingga dapat digunakan sebagai bahan baku pembuatan sediaan krim pelembab. Hasil pengamatan organoleptis sediaan dapat dilihat pada Tabel 2.

Penentuan identitas zat berkhaziat secara kualitatif bertujuan untuk mengetahui keberadaan senyawa aktif sukrosa dalam ekstrak dan sediaan krim. Pengujian dilakukan dengan menggunakan pereaksi Molisch dan hasil pengujian menunjukkan bahwa sediaan krim pelembab ekstrak air buah pepaya positif mengandung senyawa aktif sukrosa yang ditandai dengan terbentuknya warna ungu pada larutan ekstrak (Gambar 1).

TABEL 2. Hasil Pemeriksaan Standarisasi Ekstrak Air Buah Pepaya (Carica papaya L.)

\begin{tabular}{|c|c|c|c|c|}
\hline Standarisasi & Parameter & $\begin{array}{l}\text { Hasil } \\
\text { Pengamatan }\end{array}$ & Persyaratan & Keterangan \\
\hline \multirow[t]{6}{*}{ Non Spesifik } & Kadar air (\%) & $2,14 \pm 0,1$ & $\leq 10 \% *)$ & Sesuai \\
\hline & Susut pengeringan (\%) & $2,67 \pm 0,03$ & $\leq 10 \% *)$ & Sesuai \\
\hline & Kadar abu total (\%) & $0,83 \pm 0,03$ & - & - \\
\hline & Kadar abu tidak larut asam & $0,19 \pm 0,006$ & - & - \\
\hline & (\%) & $0,46 \pm 0,03$ & - & - \\
\hline & Kadar abu larut air (\%) & & & \\
\hline \multirow[t]{7}{*}{ Spesifik } & Organoleptis : & & & \\
\hline & - Warna & Putih kekuningan & Putih kekuningan ${ }^{* *}$ ) & Sesuai \\
\hline & - $\quad \mathrm{Bau}$ & Bau khas pepaya & Bau khas pepaya**) & Sesuai \\
\hline & - Bentuk & Serbuk homogen & Serbuk homogen ${ }^{* *}$ ) & Sesuai \\
\hline & Pemeriksaan pH & $5,08 \pm 0,02$ & $\left.5,0-6,5^{* *}\right)$ & Sesuai \\
\hline & Kadar sari larut air (\%) & $95,32 \pm 0,88$ & - & - \\
\hline & Kadar sari larut etanol (\%) & $2,26 \pm 0,24$ & - & - \\
\hline
\end{tabular}

Keterangan: *)Pustaka: Departemen Kesehatan RI, 2008

**)Pustaka: Sertifikat Analisis PT. Natura Laboratoria Prima

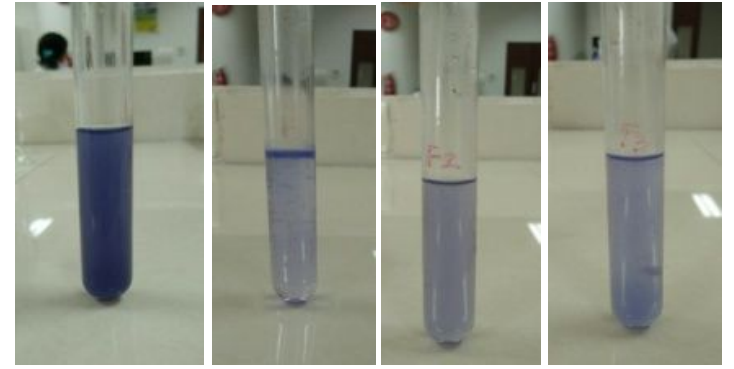

GAMBAR 2. Hasil Penentuan Identitas Senyawa Aktif Sukrosa pada Sediaan Krim Pelembab Ekstrak Air Buah Pepaya (Carica papaya L.)

Berdasarkan hasil pengamatan organoleptis yang dilakukan terhadap kelima formula sediaan krim pelembab ekstrak air buah pepaya (Carica papaya L.) diperoleh formula 1, 2, dan 3 memiliki warna putih kekuningan sampai orange. Hal tersebut disebabkan karena adanya peningkatan konsentrasi ekstrak kering buah pepaya yang ditambahkan, sedangkan blangko 1 dan blangko 2 memiliki warna putih dikarenakan tanpa adanya penambahan ekstrak. Hasil pengamatan organoleptis sediaan dapat dilihat pada Gambar 2.

Pengujian $\mathrm{pH}$ dilakukan dengan tujuan untuk mengetahui derajat keasaman suatu sediaan untuk mencegah terjadinya iritasi pada kulit saat krim digunakan. Dimana $\mathrm{pH}$ ideal untuk sediaan topikal antara 6,0-7,0 (Singh et al, 2011). Berdasarkan hasil percobaan diperoleh bahwa kelima formula memenuhi spesifikasi yang diharapkan yang dapat dilihat pada Tabel 3 . Peningkatan konsentrasi ekstrak berpengaruh terhadap nilai $\mathrm{pH}$ sediaan krim ekstrak buah papaya, dimana semakin banyak jumlah ekstrak yang ditambahkan maka menyebabkan penurunan nilai $\mathrm{pH}$.

Hal tersebut disebabkan oleh nilai $\mathrm{pH}$ ekstrak pepaya yang cenderung bersifat asam. Uji tipe emulsi bertujuan untuk mengetahui tipe emulsi dari sediaan yang dihasilkan. Persyaratan umum untuk tipe emulsi sediaan krim pelembab adalah tipe minyak dalam air (Lubis dkk, 2012). Berdasarkan hasil percobaan diperoleh bahwa kelima formula menunjukkan hasil tipe emulsi minyak dalam air dan memenuhi spesifikasi yang diharapkan. Hal ini dibuktikan dengan larutan metilen blue sebagai pewarna yang larut dalam air mampu tersebar merata pada sediaan dan adanya penambahan ekstrak pada berbagai konsentrasi yang berbeda tidak mempengaruhi tipe emulsi sediaan.

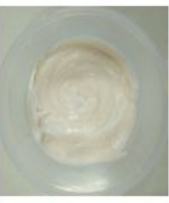

(A)

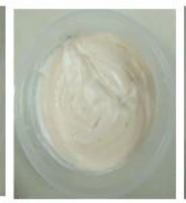

(B)

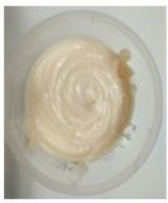

(C)

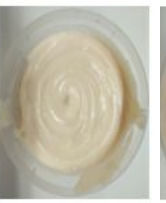

(D)

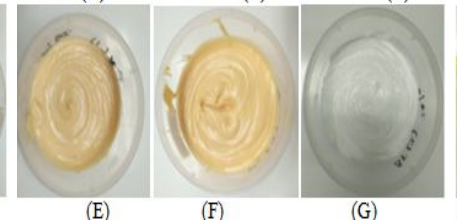

(G)

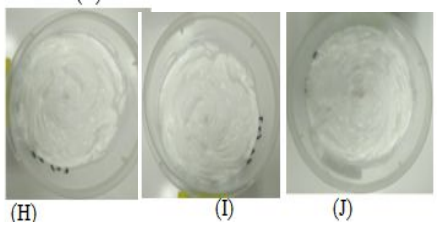

(J)

GAMBAR 2. Hasil Pengamatan Organoleptis Sediaan Krim Pelembab Ekstrak Air Kering Buah Pepaya

(Carica papaya L.) 
Pengujian viskositas bertujuan untuk mengetahui tingkat kekentalan dari sediaan dengan menggunakan Viscometer Brookfield. Rentang spesifikasi yang diharapkan sesuai dengan persyaratan viskositas sediaan krim yang baik yakni 30000-700000 cPs (Buhse et al, 2005). Berdasarkan hasil percobaan diperoleh bahwa peningkatan konsentrasi ekstrak buah papaya akan meningkatkan nilai viskositas sediaan krim. Hal ini disebabkan karena peningkatan konsentrasi ekstrak buah papaya yang menyebabkan jumlah air dalam sediaan juga semakin sedikit sehingga sediaan semakin kental. Sedangkan formula blangko tanpa adanya penambahan ekstrak tidak terlalu mengalami peningkatan nilai viskositas yang signifikan.

Pengujian daya sebar dilakukan untuk mengetahui kemampuan menyebar sediaan pada kulit saat diaplikasikan. Spesifikasi sediaan krim pelembab adalah dapat menyebar dengan mudah dan merata, dengan daya sebar yang dikehendaki untuk sediaan krim adalah 3 sampai $7 \mathrm{~cm}$ (Garg et $a l$, 2002). Berdasarkan hasil percobaan diperoleh bahwa peningkatan konsentrasi ekstrak berpengaruh pada kemampuan daya sebar sediaan. Dimana semakin tinggi konsentrasi ekstrak yang digunakan, maka kemampuan menyebar sediaan krim esktrak buah pepaya juga akan menurun. Hal tersebut dipengaruhi oleh viskositas sediaan, dimana semakin tinggi kosnentrasi ekstrak juga menyebabkan peningkatan viskositas sediaan krim sehingga kemampuan menyebar sediaan juga akan menurun. Hasil pengujian daya sebar dapat dilihat pada Tabel 3 .

Uji homogenitas bertujuan untuk mengetahui sediaan yang dibuat homogen atau tidak yang ditandai dengan ada atau tidaknya butiran kasar yang terlihat pada sediaan (Indrawati dan Sari, 2010). Pengujian dilakukan secara visual dengan mengoleskan sediaan pada kaca transparan. Berdasarkan hasil pengamatan yang dilakukan menunjukkan bahwa semua formula yang dibuat memberikan hasil yang homogen dan sesuai spesifikasi sediaan yang diharapkan. Hasil pengujian homogenitas dapat dilihat pada Tabel 3 .

Pengujian ini dilakukan dengan tujuan untuk mengetahui kemudahan sediaan krim ekstrak buah pepaya untuk dibersihkan dari kulit saat dicuci dengan menggunakan air (Anggraini, Malik dan Susiladewi, 2011). Hasil percobaan menunjukkan bahwa peningkatan konsentrasi ekstrak buah pepaya akan menyebabkan sediaan krim semakin sulit dibersihkan ditandai dengan peningkatan volume air yang dibutuhkan. Hal tersebut disebabkan oleh peningkatan kandungan gula di dalam ekstrak seiring dengan peningkatan konsentrasi ekstrak sehingga sediaan krim terasa semakin lekat di permukaan kulit. Hasil daya tercucikan air selengkapnya dapat dilihat pada Tabel 3.
Pengujian daya lekat bertujuan untuk mengetahui kemampuan melekat sediaan ketika diaplikasikan pada permukaan kulit. Berdasarkan hasil percobaan diperoleh bahwa kelima formula menunjukkan sediaan tidak lekat dengan waktu uji kurang dari 1 menit. Secara teoritis nilai daya lekat berbanding lurus dengan viskositas sediaan yang dihasilkan (Ikhsanudin, 2012). Peningkatan konsentrasi ekstrak juga berpengaruh terhadap nilai daya lekat, dimana semakin tinggi konsentrasi ekstrak yang ditambahkan maka waktu melekat dari sediaan juga semakin lama. Hasil pengujian dilihat pada Tabel 3.

Pada keseluruhan hasil evaluasi mutu fisik formula 1, 2 dan 3 memenuhi seluruh spesifikasi yang diharapkan sehingga dapat disimpulkan bahwa ketiga formula tersebut memenuhi karakteristik sebagai sediaan krim pelembab yang baik. Penentuan nilai efektivitas dilakukan untuk mengetahui kemampuan sediaan untuk mempertahankan kadar air di kulit secara in vitro menggunakan metode SDT (Sorption Desorption Test) dengan parameter nilai [AUC] (Barel, Paye and Maibach, 2009; Aghace et al, 2001). Penentuan nilai efektivitas dihitung berdasarkan nilai $[\mathrm{AUC}]_{\text {total }}$ yang ditentukan terhadap jumlah berat yang hilang saat pemanasan di oven. Dimana semakin kecil persen bobot yang hilang maka efektivitas kelembabannya semakin tinggi, begitu pula sebaliknya. Berdasarkan hasil pengujian diketahui bahwa peningkatan konsentrasi ekstrak memberikan pengaruh terhadap peningkatan daya melembabkan kulit. Hal tersebut dapat dibuktikan dengan parameter $[\mathrm{AUC}]_{\text {total }}$ dari formula yang mengandung ekstrak dengan konsentrasi makin tinggi, maka nilai $[\mathrm{AUC}]_{\text {total }}$ makin kecil. Sedangkan daya melembabkan sediaan krim ekstrak buah pepaya dengan parameter nilai $[\mathrm{AUC}]_{\text {total }}$ bila dibandingkan dengan nilai [AUC $]_{\text {total }}$ blangko 2 (tanpa ekstrak dan humektan) dan blangko 1 (mengandung humektan sintetik) ternyata memiliki nilai $[\mathrm{AUC}]_{\text {total }}$ yang lebih kecil, yang berarti sediaan krim ekstrak buah pepaya memiliki kemampuan mengurangi hidrasi kulit lebih baik dibandingkan sediaan blangko 1 dan 2 (Gambar 3). Hal ini membuktikan bahwa formula 3 dengan konsentrasi ekstrak tertinggi 30\% memiliki kemampuan melembabkan kulit terbaik. Hasil pengujian efektivitas dapat dilihat pada Tabel 3.

Persyaratan suatu sediaan krim yang baik adalah tidak mengiritasi (Mitsui, 1997). Iritasi ditandai adanya kemerahan, gatal-gatal, dan bengkak pada kulit. Berdasarkan hasil percobaan diperoleh bahwa kelima formula sediaan krim tidak menimbulkan iritasi pada kulit. Hal ini menunjukkan bahwa seluruh formula sediaan pelembab ekstrak air buah pepaya (Carica papaya L.) memenuhi spesifikasi yang diharapkan yaitu tidak mengiritasi dan aman ketika diaplikasikan pada kulit. Hasil uji iritasi sediaan dapat dilihat pada Tabel 3. 


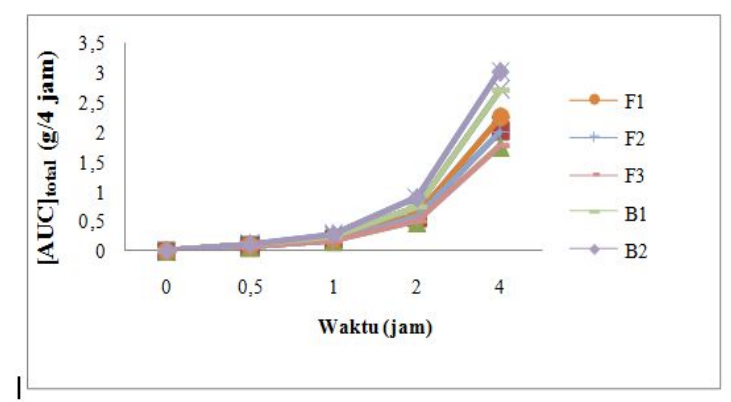

Gambar 3. Grafik yang Menunjukkan Hubungan Antara Waktu terhadap [AUC] $]_{\text {Total }}$ yang Dilihat dari Selisih Berat Hidro Gel yang Hilang pada Jam ke- o, 0,5, 1, 2 dan 4 untuk Sediaan Krim Pelembab Ekstrak Air Buah Pepaya (Carica papaya $\mathrm{L}$.)

Keterangan: F1 (sediaan dengan ekstrak 10\%), F2 (sediaan dengan ekstrak 20\%), F3 (sediaan dengan ekstrak 30\%), B1 (basis tanpa ekstrak), B2 (basis tanpa ekstrak dan tanpa humektan).

Uji aseptabilitas dilakukan untuk mengukur tingkat kesukaan sediaan dengan menggunakan blangko penilaian. Hasil yang diharapkan dari uji aseptabilitas sediaan krim pelembab adalah disukai dengan kriteria mudah diratakan, terasa dingin dan mudah dibersihkan. Berdasarkan hasil pengujian, formula 3 agak kurang disukai karena menimbulkan rasa lengket yang disebabkan karena kandungan gula dan maltodekstrin dari ekstrak. Hasil pengujian dapat dilihat pada Tabel 3 .

Pengujian stabilitas dilakukan untuk mengetahui kestabilan dari sediaan selama waktu penyimpanan. Sediaan dikatakan stabil apabila tidak mengalami perubahan dari kondisi awal pembuatan. Pengamatan yang dilakukan pada uji stabilitas meliputi pengamatan organoleptis, $\mathrm{pH}$ dan viskositas. Pada pengamatan organoleptis sediaan pelembab ekstrak air buah pepaya menunjukkan tidak ada perubahan bentuk dan bau. Pada pengujian stabilitas $\mathrm{pH}$ terjadi penurunan nilai $\mathrm{pH}$ pada penyimpanan namun penurunan yang terjadi tidak terlalu signifikan. Pengujian stabilitas dengan metode sentrifugasi menunjukkan tidak terjadi pemisahan fase dan dapat dikatakan stabil dan memenuhi spesifikasi. Hasil pengujian stabilitas sediaan menunjukkan bahwa seluruh sediaan masih dalam keadaan yang stabil dan hasil pengujian dapat dilihat pada Gambar 4.

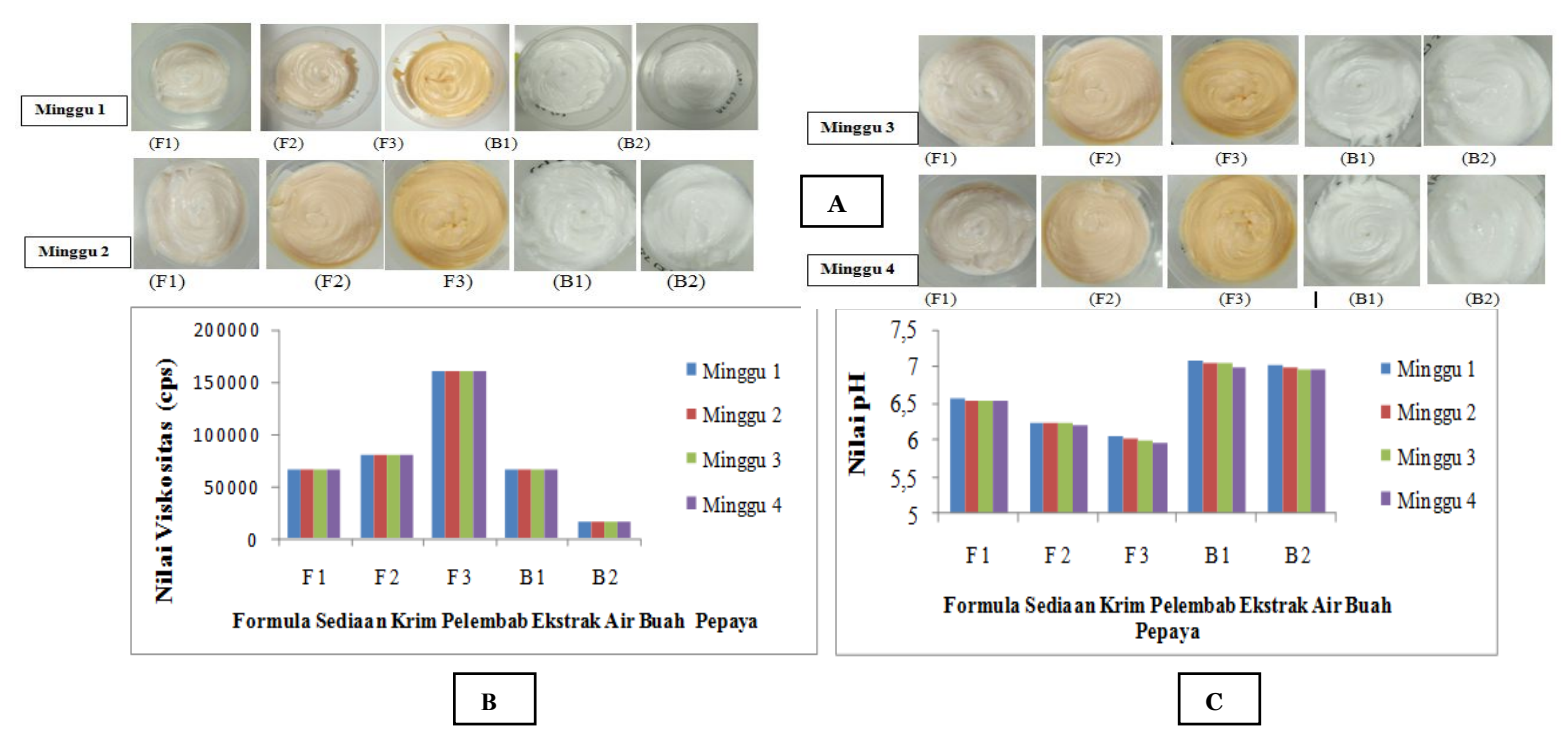

Gambar 4. Hasil Pengamatan Stabilitas Sediaan Krim Pelembab Ekstrak Air Buah Pepaya (Carica papaya L.)

Keterangan: (A) organoleptis, (B) stabilitas nilai pH sediaan, (C) stabilitas viskositas sediaan

\section{KESIMPULAN}

Berdasarkan hasil pengamatan pada penelitian ini dapat disimpulkan bahwa ekstrak buah pepaya dapat diformulasikan menjadi sediaan krim pelembab ekstrak air buah pepaya (Carica papaya L.) dan dengan adanya peningkatan variasi konsentrasi ekstrak sebesar 10\%, 20\%, dan 30\% mampu memberikan pengaruh terhadap efektivitas sediaan sebagai pelembab. Semakin besar konsentrasi ekstrak buah pepaya yang ditambahkan dalam sediaan krim maka akan meningkatkan kemampuan sediaan untuk mengurangi hidrasi kulit. Peningkatan konsentrasi ekstrak buah pepaya juga berpengaruh terhadap hasil uji mutu fisik, keamanan, aseptabilitas dan stabilitas sediaan krim pelembab ekstrak air buah pepaya (Carica papaya L.). Berdasarkan keseluruhan hasil pengujian sediaan, diketahui formula sediaan yang memiliki karakteristik sediaan krim pelembab terbaik adalah formula 3 dengan konsentrasi ekstrak sebesar 30\%. 
Tabel3. Hasil uji sediaan pelembab ekstrak air buah pepaya

\begin{tabular}{|c|c|c|c|c|c|c|}
\hline Kriteria Uji & Formula 1 & Formula 2 & Formula 3 & Blangko 1 & Blangko 2 & Spesifikasi \\
\hline \multicolumn{7}{|l|}{ Mutu Fisik } \\
\hline Organoleptis & & & & & & \\
\hline -Warna & $\begin{array}{c}\text { Putih } \\
\text { kekuningan }\end{array}$ & $\begin{array}{c}\text { Putih } \\
\text { kekuningan }\end{array}$ & Orange & Putih & Putih & $\begin{array}{l}\text { Putih kekuningan- } \\
\text { orange }\end{array}$ \\
\hline -Bau & Khas pepaya & Khas pepaya & Khas pepaya & Tidak berbau & Tidak berbau & Khas pepaya \\
\hline -Bentuk & Krim & Krim & Krim & Krim & Krim & $\begin{array}{l}\text { Krim } \\
\qquad 6,5 \pm 0,5\end{array}$ \\
\hline $\mathrm{pH}$ & $6,56 \pm 0,01$ & $6,25 \pm 0,02$ & $6,04 \pm 0,01$ & $7,08 \pm 0,01$ & $7,01 \pm 0,01$ & $\begin{array}{c}\text { (Tranggono } \\
\text { dan Latifa, } \\
\text { 2007) }\end{array}$ \\
\hline Tipe emulsi & Minyak dalam air & Minyak dalam air & Minyak dalam air & Minyak dalam air & Minyak dalam air & $\begin{array}{l}\text { Minyak dalam air } \\
\text { (Panda, 2000) }\end{array}$ \\
\hline Viskositas & $66110,00 \pm 583,33$ & $80266,66 \pm 613,01$ & $159710,00 \pm 519,81$ & $65098,33 \pm 516,31$ & $15910,00 \pm 625,43$ & $\begin{array}{l}\text { 3000o-70oooocps } \\
\text { (Bushe, 2003) }\end{array}$ \\
\hline Daya sebar & $5,85 \pm 0,04$ & $4,48 \pm 0,07$ & $3,63 \pm 0,05$ & $6,31 \pm 0,07$ & $6,45 \pm 0,05$ & $\begin{array}{l}3-7 \mathrm{~cm} \\
\text { (Garg et al, } \\
\text { 2002) }\end{array}$ \\
\hline Homogenitas & Homogen & Homogen & Homogen & Homogen & Homogen & $\begin{array}{c}\text { Homogen } \\
\text { (Voigt, 1994) }\end{array}$ \\
\hline $\begin{array}{c}\text { Daya } \\
\text { tercucikan air }\end{array}$ & $10,30 \pm 0,22$ & $11,52 \pm 0,13$ & $13,48 \pm 0,15$ & $9,90 \pm 0,14$ & $9,40 \pm 0,15$ & $\begin{array}{l}\text { 10-20 ml } \\
\text { (tercucikan air) } \\
\text { (Anggraini, Malik } \\
\text { dan Susiladewi, } \\
\text { 2011) }\end{array}$ \\
\hline Daya lekat & $\begin{array}{l}42,22 \pm 008 \\
\quad(\text { detik) }\end{array}$ & $\begin{array}{l}43,52 \pm 0,11 \\
\quad \text { (detik) }\end{array}$ & $\begin{array}{l}\text { 6o,05 } \pm 0,26 \\
\quad \text { (detik) }\end{array}$ & $\begin{array}{l}\text { 6,55 } \pm 0,08 \\
\text { (detik) }\end{array}$ & $\begin{array}{l}5,89 \pm 0,11 \\
\quad(\text { detik) }\end{array}$ & Tidak lekat $<1$ menit \\
\hline \multicolumn{7}{|l|}{ Efektifitas } \\
\hline $\begin{array}{c}\text { Nilai } \\
{[\text { AUC]total }}\end{array}$ & $\begin{array}{c}3,14 \pm 0,01 \\
(\mathrm{~g} / 4 \mathrm{jam})\end{array}$ & $\begin{array}{c}2,83 \pm 0,12 \\
(\mathrm{~g} / 4 \mathrm{jam})\end{array}$ & $\begin{array}{c}2,46 \pm 0,06 \\
(\mathrm{~g} / 4 \mathrm{jam})\end{array}$ & $\begin{array}{c}3,76 \pm 0,04 \\
(\mathrm{~g} / 4 \mathrm{jam})\end{array}$ & $\begin{array}{c}4,28 \pm 0,03 \\
(\mathrm{~g} / 4 \mathrm{jam})\end{array}$ & $\begin{array}{l}\text { Nilai AUC total } \\
\text { sediaan mengandung } \\
\text { ekstrak lebih kecil } \\
\text { dibandingkan nilai } \\
\text { AUC total blangko } \\
\text { (Herawati, 2006) }\end{array}$ \\
\hline \multicolumn{7}{|l|}{ Keamanan } \\
\hline Uji iritasi & $\begin{array}{l}\text { Tidak } \\
\text { mengiritasi }\end{array}$ & $\begin{array}{l}\text { Tidak } \\
\text { mengiritasi }\end{array}$ & $\begin{array}{l}\text { Tidak } \\
\text { mengiritasi }\end{array}$ & $\begin{array}{c}\text { Tidak } \\
\text { mengiritasi }\end{array}$ & $\begin{array}{l}\text { Tidak } \\
\text { mengiritasi }\end{array}$ & $\begin{array}{c}\text { Tidak } \\
\text { mengiritasi } \\
\text { (Mitsui, 1997) }\end{array}$ \\
\hline \multicolumn{7}{|l|}{ Aseptabilitas } \\
\hline $\begin{array}{l}\text { Uji kesukaan } \\
\text { Stabilitas }\end{array}$ & Disukai & Disukai & Disukai & Disukai & Disukai & Disukai \\
\hline Suhu kamar & Stabil & Stabil & Stabil & Stabil & Stabil & $\begin{array}{c}\text { Stabil secara } \\
\text { organoleptis, pH, } \\
\text { Viskositas }\end{array}$ \\
\hline Sentrifugasi & Stabil & Stabil & Stabil & Stabil & Stabil & $\begin{array}{l}\text { Stabil tidak terjadi } \\
\text { pemisahan fase }\end{array}$ \\
\hline Cycling test & Stabil & Stabil & Stabil & Stabil & Stabil & $\begin{array}{l}\text { Stabil tidak terjadi } \\
\text { pemisahan fase }\end{array}$ \\
\hline
\end{tabular}

\section{DAFTAR PUSTAKA}

Agache P., Mary S., Muret P., Matta A. M., Humbert P., 2001. Assessment of the Water Content of the Stratum Corneum Using a Sorption-Desorption Test, Dermatology Unit, Laboratory of Engineering and Cutaneous Biology, University Hospital, France.

Anggraini, D., Malik, M., dan Susiladewi, M., 2011. Formulasi Krim Serbuk Getah Buah Pepaya (Carica papaya L.) sebagai Anti Jerawat, Disertasi, Fakultas Farmasi, Universitas Andalas, Padang.

Aswal, A., Kalra, M., and Rout, A. 2013. Preparation and evaluation of polyherbal cosmetic cream, Der Pharmacia Lettre, 5(1):83-88.

Barel. A. O., Paye, M., Maibach H.I. 2009. Handbook of Cosmetic Science and Technology, 3rd ed., Informa Healthcare USA Inc, New York, USA.

Buhse, L., Kolinski, R., Westenbeger, B., Wokovich, A., Spencer, J., Chen, C.W., Turujman, S., Gautam-Basak, M., Kang, G.J., Kibbe, A., Heintzelman, B., Wolfgang, E., 2005. Topical drug classification, Int.J. Pharm., 13;295(1-2):101-12.

Dirjen POM, 2000. Parameter Standar Umum Ekstrak
Tumbuhan Obat Cetakan Pertama, Jakarta: Departemen Kesehatan Republik Indonesia.

Desai, UT., and Wagh, AN., 1995. Papaya in Handbook of Fruit Science and Technology Production, Composition, Storage, and Processing, Marcel Dekker, Inc, New York.

Dewi, D.A.R., 2010. 'Penambahan Saccharide Isomerates 5\% dalam Formulasi Pelembab Meningkatkan Hidrasi Kulit Lebih Tinggi Dibandingkan Pelembab Biasa', Tesis, Sarjana Farmasi, Universitas Udayana, Denpasar.

Djajadisastra, J., 2004. Cosmetic Stability, Departemen Farmasi Fakultas Matematika dan Ilmu Pengetahuan Alam Universitas Indonesia Depok: Seminar Setengah Hari HIKI.

Ferida, T., 2011. 'Penggunaan Sari Buah Pepaya (Carica papaya L.) dalam Sediaan Krim Pelembab', Skripsi, Sarjana Farmasi, Universitas Sumatera Utara.

Garg, A., Aggarwal, D., Garg, S., and Sigla, A.K., 2002. Spreading of Semisolid Formulation, Pharmaceutical Technology. Pharmaceutical Technology. www.pharmtech.com 
Herawati, R. 2006. 'Pengaruh Gliserin Terhadap Stabilitas Fisik dan Efektivias Ekstrak Kering Aloe vera Sebagai Pelembab dalam Basis Vanishing Cream', Skripsi, Sarjana Farmasi, Universitas Airlangga, Surabaya.

Ikhsanudin, A., 2012. Formulasi Vanishing Cream Minyak Atsiri Rimpang Jahe (Zingiber officinale R.) dan Uji Aktivitas Repelan terhadap Nyamuk Aedes aegypti Betina, Jurnal Ilmiah, 2(2):175-186.

Indrawati, T., dan Sari, H.Y., 2010. 'Pengaruh Butter Alpukat (Avocado butter) terhadap Karakteristik Krim Pelembut tipe A/M', Skripsi, Fakultas Farmasi, Universitas Pancasila, Jakarta.

Inglet and Charalambous, 1979. Tropical Foods:Chemistry and nutrition, From Academic Press, Jakarta.

Kumbasari, A., 2015. Analisis Kualitatif Kandungan Sakarida Dalam Tepung dan Pati Umbi Ganyong (Canna Edulis Ker.), Pharmaçiana, 5(1):35-42.
Lubis, E.S., Lubis, L.S. dan Reveny, J., 2012. Pelembab Kulit Alami dari Sari Buah Jeruk Bali [Citrus maxima(Burm.) Osbeck], Journal of Pharmaceutics and Pharmacology, 1(2):104-111.

Mitsui, T., 1997. New Cosmetic Science, Elsevier Science, The Netherlands, p.210-211, 342.

Panda, H., 2000. Herbal Cosmetics Handbook, Asia Pacific Business Press, Delhi, India.

Singh, M., Sharma, S., Khokra, S.L., Sahu, R.K., and Jangde, R., 2011. Preparation and Evaluation of Herbal Cosmetic Cream, India, Pharmacologyonline 2:pp 1258-1264.

Voigt, R. 1994. Buku Pelajaran Teknologi Farmasi edisi 5. Terjemahan Soewandhi, S.N., Penerbit Gadjah Mada University Press, Yogyakarta.

Wasitaatmadja, S.M., 1997. Penuntun Ilmu Kosmetik Medik, Penerbit Universitas Indonesia, Jakarta, Hal. 3,58-59, 62-63, 111-112. 